Brit. J. vener. Dis. (1959), 35, 77.

\title{
SIGNIFICANCE OF SACRO-ILIITIS IN REITER'S DISEASE*
}

\author{
BY \\ GEORGE W. CSONKA \\ St. Mary's Hospital, London, W.2
}

Despite the increasing recognition of spinal and particularly sacro-iliac involvement in Reiter's disease, there is little information on the effect of such involvement on the course and prognosis of the disease and much divergence of opinion as to its relationship to "classical" ankylosing spondylitis.

\section{Material}

166 patients with Reiter's disease attended St. Mary's Hospital between January, 1947, and December, 1956. All but 21 cases were personally seen. Much of the clinical material has previously been reported as part of a larger series describing the course of the illness (Csonka, 1958; Reynolds and Csonka, 1958), but since then an attempt has been made to trace all patients again and examine or re-examine them for radiological evidence of sacro-iliitis. 32 patients, who defaulted within 2 years of onset, could not be traced and are excluded from this study. Of the remaining 134, radiological changes in the sacroiliac joints such as are found in ankylosing spondylitis were seen in 27 , and one of them also had spinal changes. In some of the patients the symptoms had started while they were attending elsewhere, of ten years before the period of the present study: in these cases verification of the diagnosis was sought from the hospital or doctor concerned. The progress and clinical features of the group

TABLE I

FOLLOW-UP OF PATIENTS WITH REITER'S DISEASE AND ANKYLOSING SPONDYLITIS

\begin{tabular}{|c|c|c|c|}
\hline \multirow[b]{2}{*}{$\underset{(y r s)}{\text { Duration }}$} & \multicolumn{3}{|c|}{ No. of Patients with } \\
\hline & $\begin{array}{c}\text { Reiter's Disease } \\
\text { without } \\
\text { Sacro-iliitis } \\
(107)\end{array}$ & $\begin{array}{c}\text { Reiter's Disease } \\
\text { with } \\
\text { Sacro-iliitis } \\
\text { (27) }\end{array}$ & $\begin{array}{c}\text { Ankylosing } \\
\text { Spondylitis } \\
\text { (50) }\end{array}$ \\
\hline $\begin{array}{c}2- \\
3- \\
4- \\
5- \\
10- \\
15- \\
20- \\
25+\end{array}$ & $\begin{array}{r}31 \\
14 \\
13 \\
22 \\
8 \\
12 \\
4 \\
3\end{array}$ & $\begin{array}{l}4 \\
- \\
-7 \\
8 \\
3 \\
3 \\
2\end{array}$ & $\begin{array}{r}12 \\
3 \\
5 \\
13 \\
9 \\
4 \\
4 \\
-\end{array}$ \\
\hline Mean (yrs) & 8 & $11 \cdot 7$ & $8 \cdot 6$ \\
\hline
\end{tabular}

* Paper read to the M.S.S.V.D. on November 28, 1958. Received for publication December 22, 1958. of patients with and without sacro-iliitis were compared with each other and with the medical records of fifty consecutive cases attending St. Mary's Hospital with "classical" ankylosing spondylitis during the period of this study. Follow-up details are shown in Table I.

It seems likely that a high proportion of early defaulters had mild and brief attacks. A number of such patients who defaulted early in the period of review were seen again by chance some years later because of fresh venereal infection, and it was then found that they had remained well after the early mild attacks and had seen no necessity to attend follow-up clinics.

Table II shows some of the clinical features of the three groups. When ankylosing spondylitis is compared with Reiter's disease with sacro-iliitis, there are notable differences in age and sex incidence, type of onset, proportion of peripheral joint and spinal involvement, and incidence of iritis. These differences reach at least the 5

TABLE II

CLINICAL FEATURES

\begin{tabular}{|c|c|c|c|c|c|}
\hline \multirow{2}{*}{ Diagnosis } & \multirow{2}{*}{$\cdots$} & \multirow{2}{*}{$\cdots$} & \multicolumn{2}{|c|}{ Reiter's Disease } & \multirow{2}{*}{$\begin{array}{l}\text { Ankylosing } \\
\text { Spondylitis }\end{array}$} \\
\hline & & & $\begin{array}{c}\text { Without } \\
\text { Sacro-iliitis }\end{array}$ & $\begin{array}{c}\text { With } \\
\text { Sacro-iliitis }\end{array}$ & \\
\hline \multicolumn{2}{|c|}{ Number of Cases ... } & $\cdots$ & 107 & 27 & 50 \\
\hline \multirow{2}{*}{ Sex } & Male & . & 105 & 26 & 44 \\
\hline & Female & . & 2 & 1 & 6 \\
\hline \multicolumn{3}{|c|}{ Average Age at Onset (yrs) } & $30 \cdot 8$ & $29 \cdot 0$ & $22 \cdot 6$ \\
\hline \multirow{2}{*}{$\begin{array}{l}\text { Type of Onset } \\
\text { (per cent.) }\end{array}$} & Acute & $\cdots$ & $99 \cdot 1$ & $96 \cdot 3$ & $12 \cdot 0$ \\
\hline & Spinal & . & 0 & $3 \cdot 7$ & $94 \cdot 0$ \\
\hline \multicolumn{3}{|c|}{$\begin{array}{l}\text { Peripheral Joint Involvement } \\
\text { at Some Stage of the Illness }\end{array}$} & $100 \cdot 0$ & $96 \cdot 3$ & $10 \cdot 0$ \\
\hline \multicolumn{3}{|c|}{ Radiological Changes/Spine } & $?^{*}$ & $3 \cdot 7$ & $72 \cdot 3$ \\
\hline \multirow{2}{*}{$\begin{array}{c}\text { Eye Involve- } \\
\text { ment } \quad \cdots\end{array}$} & Conjuncti & ivitis & $33 \cdot 6$ & $26 \cdot 0$ & 0 \\
\hline & Iritis/Uvei & itis & $12 \cdot 1$ & $48 \cdot 1$ & $22 \cdot 1$ \\
\hline \multicolumn{3}{|c|}{ Keratoderma Blennorrhagica } & $13 \cdot 3$ & $18 \cdot 5$ & $\mathbf{0}$ \\
\hline \multicolumn{2}{|c|}{ Circinate Balanitis } & $\cdots$ & $21 \cdot 5$ & $18 \cdot 5$ & 0 \\
\hline \multicolumn{2}{|c|}{ Plantar Fasciitis } & $\cdots$ & $14 \cdot 0$ & $30 \cdot 0$ & 0 \\
\hline
\end{tabular}

* Only a small proportion of this group had radiological investigation of the spine. 
per cent. level of significance when assessed by the $\chi^{2}$ test. Conjunctivitis, keratoderma, balanitis, and plantar fasciitis, which are prominent in the Reiter's group, do not occur in ankylosing spondylitis. When the two types of Reiter's disease are compared with each other, the differences, apart from sacro-iliac involvement, are far less striking. They include differences in the incidence of iritis and plantar fasciitis, which is higher in the group with sacro-iliitis. In passing, it may be noted that the proportion of iritis in this selected group (almost 50 per cent.) must be amongst the highest known in association with rheumatic disease. The patients with sacro-iliitis were generally more severely affected than those without this lesion and the quantitative differences of the features mentioned may be an expression of this severity.

Table III shows the frequency of some rheumatic complaints in the families of the patients and to this is added a recent series of 100 cases with uncomplicated non-specific urethritis. Ankylosing spondylitis occurred only in the families of the spondylitis group and the incidence of 8 per cent. is in accordance with general experience (Stecher, Soloman, and Wolpaw, 1952; Wilkinson and Bywaters, 1958). The only instance of familial Reiter's disease occurred in a brother of a patient with Reiter's disease without sacro-iliitis; a common sexual source was denied. The frequency with which rheumatoid arthritis appeared in the families of patients with Reiter's disease should stimulate further studies.

TABLE III

FAMILY HISTORY

\begin{tabular}{|c|c|c|c|c|c|}
\hline \multirow{3}{*}{\multicolumn{2}{|c|}{ Relatives' Status }} & \multicolumn{4}{|c|}{ Patients' Status } \\
\hline & & \multicolumn{2}{|c|}{ Reiter's Disease } & \multirow[b]{2}{*}{$\begin{array}{c}\text { Ankylosing } \\
\text { Spondylitis } \\
(50)\end{array}$} & \multirow[b]{2}{*}{$\begin{array}{c}\text { Un- } \\
\text { complicated } \\
\text { Non-Specific } \\
\text { Urethritis } \\
(100)\end{array}$} \\
\hline & & $\begin{array}{l}\text { With } \\
\text { Sacro- } \\
\text { iliitis } \\
\text { (27) }\end{array}$ & $\begin{array}{l}\text { Without } \\
\text { Sacro- } \\
\text { iliitis } \\
\text { (107) }\end{array}$ & & \\
\hline \multicolumn{2}{|c|}{ Rheumatoid Arthritis } & 2 & 12 & 5 & 3 \\
\hline \multicolumn{2}{|c|}{ Ankylosing Spondylitis } & - & - & 4 & - \\
\hline \multicolumn{2}{|c|}{$\begin{array}{l}\text { Peripheral Arthritis } \\
\text { (type unknown) }\end{array}$} & 1 & 2 & 1 & 1 \\
\hline \multicolumn{2}{|c|}{ Reiter's Disease } & - & 1 & - & - \\
\hline \multirow{2}{*}{ Total } & No. & 3 & 15 & 10 & 4 \\
\hline & Per cent. & 11 & 14 & 20 & 4 \\
\hline
\end{tabular}

The clinical impression that Reiter's disease was generally more severe in patients with sacro-iliitis than in those without this lesion was put to the test by noting in the two groups the distribution of the full syndrome as against arthritis and genital infection only, the severity of the initial attack, the functional state, and the average period of disability (Table IV and Figs 1, 2, and 3). The evidence suggests that the group with sacro-iliitis is more severely affected from the start. The main causes of disability were the same in both groups, though their total and relative frequency differed. They include:

(1) Continued or recurrent activity in peripheral joints.
(2) Severe foot deformities,

(3) Recurrent iritis,

(4) Ankylosis of the peripheral joints.

TABLE IV

FREQUENCY OF REITER'S TRIAD IN CASES WITH AND WITHOUT SACRO-ILIITIS

\begin{tabular}{|c|c|c|c|c|}
\hline \multirow[t]{2}{*}{ Reiter's Disease } & \multicolumn{2}{|c|}{ Complete Triad } & \multicolumn{2}{|c|}{$\begin{array}{l}\text { Arthritis and Genital } \\
\text { Infection Alone }\end{array}$} \\
\hline & No. & Per cent. & No. & Per cent. \\
\hline With Sacro-iliitis . . & 20 & $74 \cdot 1^{*}$ & 7 & $25 \cdot 9$ \\
\hline Without Sacro-iliitis & 49 & $45 \cdot 7^{*}$ & 58 & $54 \cdot 3$ \\
\hline Total $\ldots$ & 69 & & 65 & \\
\hline
\end{tabular}

* The difference is significant at the 5 per cent. level $\left(\chi^{2}\right.$ test).

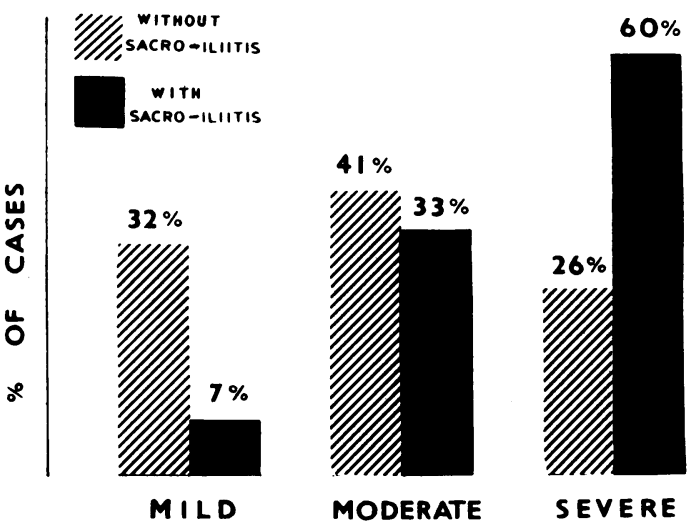

FIG. 1.-Severity of initial attack in 134 cases of Reiter's disease: MILD: Slight arthritis; no constitutional symptoms; ambulant throughout or hospitalized for less than one month.

MODERATE: Moderate arthritis; slight or no constitutional symptoms; some hospitalization necessary.

SEVERE: Severe arthritis; some constitutional symptoms; hospitalized for several months.

Lesions in the sacro-iliac joints and spine were not an important or persistent cause of symptoms. This is in contrast with the findings in cases of ankylosing spondylitis, where the major disability is located in the affected spine. It is generally accepted that, in Reiter's disease with sacro-iliitis, marked spinal involvement can occur (Marche, 1950, 1954; Ford, 1953; Sharp, 1957) but that this is distinctly rare even after years of observation, as in the present series. This difference in the anatomical involvement of the disease process, together with the other clinical dissimilarities between ankylosing spondylitis and Reiter's disease with sacro-iliitis, suggest that, in our present state of ignorance regarding aetiology, the two conditions should be regarded as separate entities.

\section{Summary}

(1) Of 134 patients with Reiter's disease, 27 (20.1 per cent.) were found to have radiological 


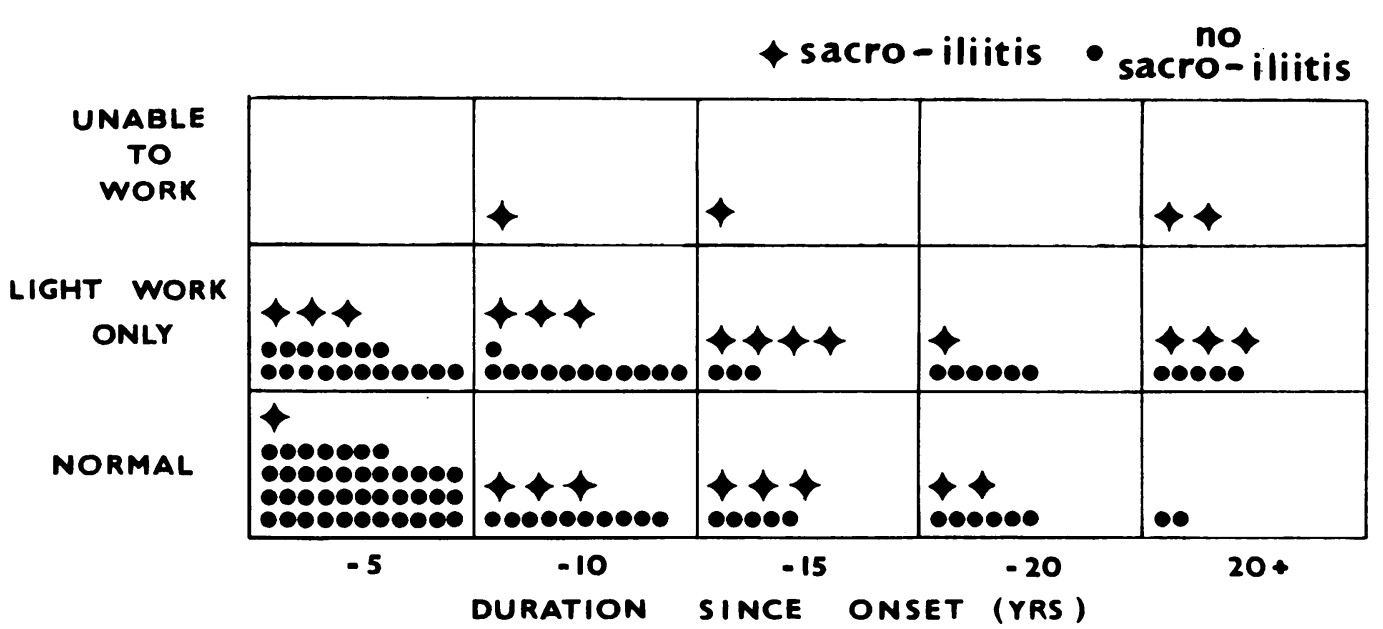

Fig. 2.-Functional status of 134 patients with Reiter's disease.

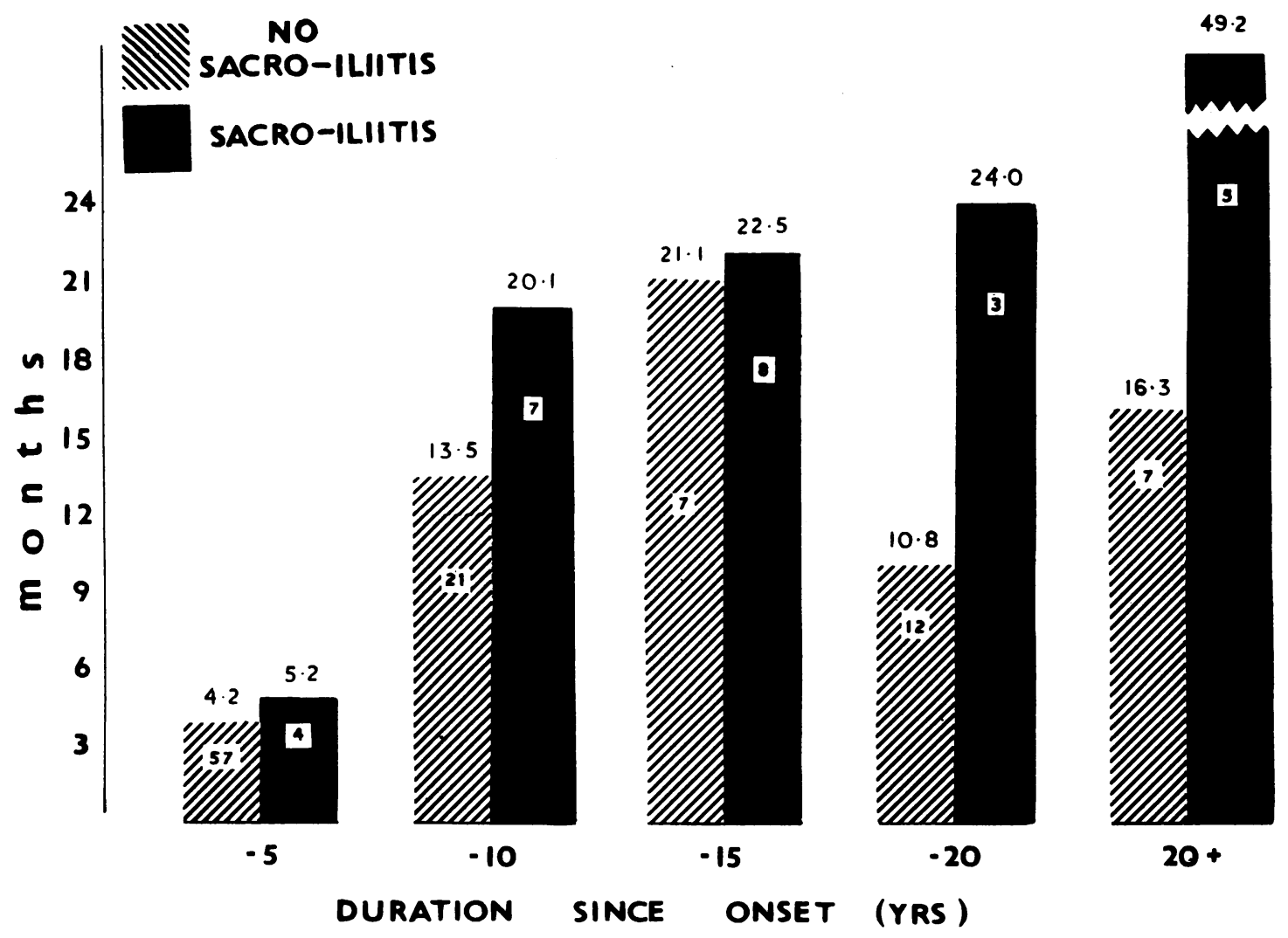

FIG. 3.-Average periods of incapacity in $\mathbf{1 3 1}$ cases of Reiter's disease (three cases omitted because duration of incapacity was not known). 
evidence of sacro-iliitis similar to that found in ankylosing spondylitis, but only one showed also some involvement of the spine.

(2) Reiter's disease with sacro-iliitis was associated with a more severe course of the illness from the start than that occurring in the group without sacro-iliac lesions. In other respects the two groups did not differ fundamentally from each other.

(3) Reiter's disease with sacro-iliitis was compared with ankylosing spondylitis. It was found that the points of difference outweighed the points of similarity, and it is suggested that for the present the two conditions should be regarded as separate entities.
I am most grateful to Dr. G. L. M. McElligott and Mr. A. J. King for much help during the preparation of this paper. This work was carried out under the aegis of the Medical Research Council Working Party on Non-Specific Urethritis, with the aid of a grant from the U.S. Public Health Service.

\section{REFERENCES}

Csonka, G. W. (1958). Brit. med. J., 1, 1088.

Ford, D. K. (1953). Ann. rheum. Dis., 12, 177.

Marche, J. (1950). Rev. Rhum., 17, 449.

(1954). Ibid., 21, 320.

Reynolds, D. F., and Csonka, G. W. (1958). J. Fac. Radiol., 9, 44.

Sharp, J. (1957). Brit. med. J., 1, 975.

Stecher, R. M., Solomon, W. M., and Wolpaw, R. (1952)

"Heredity in Rheumatoid Arthritis and Ankylosing Spondylitis", In

"Rheumatic Diseases", pp. 61-71, based on "Proc. VII. Int. Congr. rheum. Dis." (American Rheumatism Association).

Wilkinson, M., and Bywaters, E. G. L. (1958). Ann. rheum. Dis., 17, 209. 